\title{
Silence as Complicity: Elements of a Corporate Duty to Speak Out against the Violation of Human Rights
}

\author{
Florian Wettstein \\ University of St. Gallen
}

\begin{abstract}
Increasingly, global businesses are confronted with the question of complicity in human rights violations committed by abusive host governments. This contribution specifically looks at silent complicity and the way it challenges conventional interpretations of corporate responsibility. Silent complicity implies that corporations have moral obligations that reach beyond the negative realm of doing no harm. Essentially, it implies that corporations have a moral responsibility to help protect human rights by putting pressure on perpetrating host governments involved in human rights abuses. This is a controversial claim, which this contribution proposes to analyze with a view to understanding and determining the underlying conditions that need to be met in order for moral agents to be said to have such responsibilities in the category of the duty to protect human rights.
\end{abstract}

KEY WORDS: human rights, multinational corporations, silent complicity, corporate power, corporate responsibility

\section{INTRODUCTION}

$\mathrm{T}$ HE VAST MAJORITY OF CORPORATE RIGHTS VIOLATIONS,” as Stephen Kobrin (2009: 351) observes, "involve complicity, aiding and abetting violations by another actor, most often the host government." Kobrin's claim certainly seems plausible. In an increasingly interconnected world our actions affect the lives of others in ever more profound ways. Thus, increasingly we may contribute to harm without being aware of it, or at least without intending to do so. It is in the very nature of complicity that it falls "outside the paradigm of individual, intentional wrongdoing" (Kutz 2000: 1). The problem deepens if we are not merely looking at the actions of individuals, but at those of organizations that operate globally and on a large scale, such as multinational corporations. Corporations may become complicit in human rights violations although they are not doing anything wrong in a conventional sense or engaging in any unlawful conduct (Ratner 2001: 501; Brenkert 2009: 459); they may simply be going about their business. This contributes to the pervasiveness of corporate complicity and renders it notoriously hard to grasp and, not least, to condemn. The very nature of wrongdoing is changing in the process of today's globalization. ${ }^{1}$ 
The changing nature of wrongdoing in the global age must be followed by our rethinking of the parameters of moral responsibility. The fact that corporations often contribute to wrongdoings in the course of their "regular" business conduct rather than by engaging in some specific, overt and deliberate harmful activity, poses new challenges to our moral intuition and our natural sense of justice. This is why cases of corporate complicity are in a sense symptomatic for our time; they require us to rethink some of the certainties of the Westphalian age and to come up with new normative visions and concepts to deal with the new problems with which we are faced in a transnational world.

In this contribution I will show that the application of the concept of silent complicity in particular challenges conventional interpretations of corporate responsibility in profound ways. Silent complicity may appear as the least significant form of complicity simply because it does not involve an active contribution by the corporation to a specific wrongdoing. Perhaps this is why its momentous conceptual and normative implications are readily overlooked. At a closer look, acknowledging a corporation's silence as a form of complicity implies a far-reaching statement about the nature of corporate responsibility in general. This is why silent complicity merits careful study.

Specifically, I will show that silent complicity, as it is commonly defined and referred to in the relevant practical and academic debates, hinges on the existence—and subsequent violation — of positive moral obligations, rather than the merely negative duty to do no harm. More precisely, the obligation to avoid silent complicity requires that corporations which risk to become silently complicit speak out with a view to helping to protect potential or actual victims from human rights abuse. In this respect, silent complicity is distinctly different from all other forms of complicity.

The aim of this paper then is to assess under what conditions it is plausible to speak of corporations as silently complicit in human rights abuses and thus under what circumstances such a positive duty to speak out can be assumed. For this purpose, my argument must be based on several presuppositions and, accordingly, advances its claims in hypothetical form. First, my argument hinges on the assumption that, very generally, human rights impose direct moral obligations on corporations. Recent contributions to the debate have shown that such an argument can plausibly be made (see, e.g., Wettstein and Waddock 2005; Campbell 2006; Arnold 2010; Cragg 2010) and I will abstain from repeating it here. Second, if we assume that corporations do have direct human rights obligations, then the obligation not to be complicit in any form of human rights violations must necessarily be included among them. Third, if we hold that silence can, in principle, denote a form of complicity, the obligation not to be complicit in human rights violations logically includes also silent complicity.

If we hold these assumptions to be valid then the application of the concept of silent complicity to corporations implies, as a matter of consistency, that such corporations have a positive obligation to help protect the victims of human rights violations - often in opposition to and by putting pressure on perpetrating host governments. This arguably is a controversial claim. Not only does it challenge the more common perception that corporate human rights obligations are to be limited to the negative realm, but it also seems that such a corporate duty to help protect ${ }^{2}$ 
human rights goes against the defining assumptions of the waning Westphalian era: state-centrism, state sovereignty and non-interference.

Therefore, it is the aim and purpose of this contribution to shed more light on the conditions under which a corporation's failure to speak out in the face of human rights abuse can indeed be said to amount to complicity. The literature on corporate complicity in general has grown steadily in the past few years and includes normative (see, e.g., Kline 2005; Brenkert 2009, Hoffman and McNulty 2009) and legal (see, e.g., Ramasastry 2002, Clapham 2006, Clapham and Jerbi 2001, Ratner 2001) analyses of the concept, as well as analyses from the standpoint of political science (see, e.g., Kobrin 2009). However, the particularities of silent complicity have hardly been studied and dealt with at all so far. It is true that many major policy papers (see, e.g., United Nations 2008a) and initiatives (e.g., United Nations Global Compact), as well as some academic writings on complicity (see, e.g., Clapham and Jerbi 2001; Ramasastry 2002; Tripathi 2005; Kline 2005) have referred to or made use of the concept of silent complicity. However, none of them has analyzed systematically and in sufficient detail the conditions under which agents can indeed be said to be guilty of it. While at least some of them have tied silent complicity to certain requirements such as presence, authority, and/or status (Clapham and Jerbi 2001: 344; United Nations 2008a: 12), none of them has embedded them in a holistic theory or even sufficiently (or at all) clarified why and how such requirements ought to be seen as relevant for establishing silent complicity. Given the profound normative implications of silent complicity and its increasing practical relevance in a rapidly globalizing world, the lack of attention it has received in academic literature is striking.

In what follows, I argue that for a corporation to become silently complicit four conditions must be fulfilled: voluntariness, connection to the human rights violation, power to significantly influence the perpetrator, and a certain social or political status. These four conditions derive from two constitutive requirements underlying the concept of silent complicity, which I will call the "omission requirement" and the "legitimization requirement," respectively. All four conditions need to be met for silent complicity to occur.

In the first step of my argument, I will deal with some definitional aspects and outline the two constitutive requirements mentioned above. In the second step, I will derive the four conditions from the two constitutive requirements and reflect on them in the corporate context. In the third step, I will illustrate my argument with the practical example of Shell's role in Nigeria during the 1990s. I then respond to the claim that speaking out against human rights abuses would constitute illegitimate interference with a host country's sovereignty. I conclude the article with some brief reflections on legitimate corporate human rights advocacy; specifically, I will outline four safeguards to protect the public interest when corporations engage in such overtly political activity. 


\section{SILENT COMPLICITY AND THE MORAL DUTY TO HELP PROTECT}

Corporate complicity is commonly defined as "aiding and abetting" in the violation of human rights committed by a third party (see, e.g., Clapham and Jerbi 2001: 340; Kobrin 2009: 351; Ramasastry 2002: 95). Aiding and abetting is to be interpreted broadly; it includes not merely direct involvement of corporations, but also various forms of indirect facilitation.

Thus, corporate complicity can be categorized by the nature of its contribution to the wrongdoing in play. The literature on the topic commonly refers to four different forms of complicity: direct complicity, indirect complicity, beneficial complicity and silent complicity (see, e.g., Clapham and Jerbi 2001; Ramasastry 2002; Clapham 2006: 220-25). ${ }^{3}$ While direct complicity implies direct involvement of the corporation in a human rights abuse, indirect complicity involves mere facilitation, that is, an indirect contribution to the general ability of a perpetrator to commit human rights violations. There is increasing agreement that the scope of complicity may extend beyond active assistance given to a primary perpetrator. Cases of beneficial complicity, for example, do not require an active contribution by the corporation, but merely that the corporation directly or indirectly benefits from the violation of human rights. In the case of silent complicity, even "merely" standing by while human rights are violated is increasingly perceived as a form of complicity.

In contrast to other, more "conventional" forms of complicity, silent and in most cases also beneficial complicity are not established by a corporation's active contribution, but by its passive stance toward the violation of human rights. Knowingly looking the other way while the most basic rights of human beings are trampled underfoot by a host government can constitute not merely indifference, but actual support. In such cases, silence can have a potentially legitimizing or encouraging effect on a perpetrator, which in turn grounds the accusation of silent complicity (see, e.g., United Nations 2008a: 12). ${ }^{4}$ For John M. Kline (2005: 79), silent complicity "suggests that a non-participant is aware of abusive action and, although possessing some degree of ability to act, chooses neither to help protect nor to assist victims of the abuse, remaining content to meet the minimal ethical requirement to do no (direct) harm." Hence, moral blame in cases of silent complicity is not attached to certain harmful actions conducted by the corporation, but to its failure to give assistance to those in need when it is in a position to do so. In short, the main difference between silent complicity and most other forms of complicity ${ }^{5}$ is that its moral basis is not commission, but omission.

The normative implications of this insight are far-reaching. Omission denotes a failure to act in response to wrongdoing. Thus, rather than to merely passively refrain from specific harmful actions, the agent in danger of becoming silently complicit is under a moral obligation to confront and possibly counteract the wrongdoing. If silence renders companies complicit, speaking out to help protect the victims is what is required to diffuse such allegations. The claim that a corporation is silently complicit in human rights violations, as Wiggen and Bomann-Larsen (2004: 11) conclude, implies that it is guilty of omitting to fulfill an actual positive duty. 
A positive duty goes beyond the mere avoidance of doing harm to others; it includes an obligation to come to the victims' help or assistance. Thus, the obligation to avoid silent complicity, as pointed out in Kline's definition quoted above, implies a duty to "help protect" or to "assist victims of the abuse" (Kline 2005: 79). Specifically, as Andrew Clapham and Scott Jerbi (2001: 347-48) point out, silent complicity "reflects the expectation on companies that they raise systematic or continuous human rights abuses with the appropriate authorities." This is by any means a far-reaching claim. It challenges the common assumption that the moral obligations of corporations ought to be limited to the negative realm of doing no harm and, in a sense, associates them with actions and responsibilities that we normally hold to be the exclusive domain of governments. It is thus not surprising that silent complicity is noted as the "most controversial type of complicity" by the UN Global Compact. ${ }^{6}$

In sum, there are two constitutive requirements that need to be fulfilled in order for an agent to be guilty of silent complicity: first, the agent must have failed to speak out and help protect the victims. I will call this the "omission requirement." Second, the omission of this positive duty must have a legitimizing or encouraging effect on the human rights violation and the perpetrator who is committing it. I will call this the "legitimization requirement." This, in turn, raises the question: under what conditions can corporations indeed be said to be silently complicit in a host government's human rights abuse? That is, under what circumstances or conditions can these two requirements plausibly be said to be fulfilled? In what follows I will assess both requirements separately. The "omission requirement," I will argue, hinges on one general and two qualified conditions, while the "legitimization requirement" depends on a fourth condition.

\section{ASSESSING THE "OMISSION REQUIREMENT": ELEMENTS OF A POSITIVE DUTY TO SPEAK OUT AGAINST THE VIOLATION OF HUMAN RIGHTS}

A first important distinction that needs to be drawn in order to assess the "omission requirement" is the one between negative and positive duties. A negative duty is a duty to do no harm, while a positive duty is a duty to assist or "help persons in [acute] distress" (Pogge 2002: 197). Thus, a negative duty is a duty not to make a situation worse, while a positive duty is a duty to improve a given state of affairs. Negative duties are commonly seen as stricter than positive ones (Scheffler 2001: 37; see also Rawls 1971: 98), which is at the root of the controversy surrounding any argument that assigns positive duties to corporations. ${ }^{7}$

The distinction between negative and positive duties is not to be confused with the one between passive and active duties. Passive duties command us to merely abstain from certain (harmful) activities while active duties require us to actively perform specific actions. Negative duties can be active or passive. Doing no harm may be as simple as abstaining from actively hurting someone (passive), but, depending on the situation, it may also require to actively eliminate risks or dangers to others, such as cutting the tree in one's yard that threatens to fall onto the sidewalk. Pas- 
sive duties are always negative, since passively abstaining from specific actions is obligatory only if those actions are harmful to others (or, in some cases, to oneself). As a consequence, positive duties are always active. ${ }^{8}$

In his seminal work Basic Rights (1996), Henry Shue further specified those different duties for the specific context of human rights. He divided human rights obligations into duties to respect, duties to protect, and duties to realize human rights. ${ }^{9}$ Duties to respect human rights are negative duties; they command us not to directly or indirectly violate human rights. Accordingly, they can be either active or passive. A passive duty to respect demands that we abstain from actions in violation of human rights; an active duty to respect requires us to seek to eliminate or reduce dangers and threats within our sphere of influence or responsibility. Positive duties, then, include duties to protect and duties to realize human rights. Both of them demand that duty-bearers take active measures to come to the victims' assistance.

The duty to speak out against human rights violations is a positive duty. That is to say, it is a duty to speak out to help protect the victims. Thus, implicitly, as Kline's above definition makes clear, the duty to speak out is based on the expectation that doing so might potentially influence the perpetrator's actions. It is from this perspective that commonly the duty to speak out is not perceived merely as a duty to make a statement, but as a broader duty to address the issue with the appropriate authorities. For Tom Campbell (2006: 258), for example, "it must be part of the obligations of MNCs to do what they can to place pressure on abusive governments." ${ }^{10}$ In other words, an agent in danger of becoming silently complicit is not asked necessarily to withdraw from the respective country, nor to merely issue a public condemnation, ${ }^{11}$ but to use its influence to attempt to alter the actions or policies of a perpetrator or a potential perpetrator. For former UN High Commissioner for Human Rights, Mary Robinson, the increasing use of the notion of silent complicity "reflects the growing acceptance ... that there is something culpable about failing to exercise influence" in circumstances of "systematic or continuous human rights abuses" (quoted in Clapham 2006: 221; emphasis added). Similarly, for the International Council on Human Rights Policy (2002: 133; emphasis added) silent complicity implies that "A company is aware that human rights violations are occurring, but does not intervene with the authorities to try and prevent or stop the violations."

Thus, silent complicity presupposes corporate human rights obligations that reach beyond the realm of doing no harm. This conflicts with the limited view on corporate human rights obligations that has dominated the current debate on business and human rights (see, e.g., Hsieh 2009; Arnold 2010), a view that has been confirmed and reasserted by the UN Secretary-General's Special Representative on business and human rights (SRSG), John Ruggie. The result is that his proposed UN Framework locates corporate human rights obligations exclusively in the category of negative duties to respect. ${ }^{12}$ Duties to protect and to realize human rights, as a consequence, are presented as the exclusive domain of governments (see United Nations 2008b: 4).

Ruggie's main report questions the case for legal liability for silent complicity (United Nations 2008b: 21). Peculiarly, however, it seems not to rule out the application of the concept of silent complicity to corporations from a moral point 
of view, despite the limited view on corporate human rights obligations. Rather, referring to the UN Global Compact, the so-called companion report lists silent complicity among those forms of aiding and abetting in which corporations ought to avoid being implicated (see United Nations 2008a: 17). Ruggie does indicate that the companion report merely aims at clarifying how complicity relates to and fits into the merely negative corporate responsibility to respect human rights (United Nations 2008a: 1). However, it seems that if we limit corporate obligations to the negative realm of respecting human rights, then we eliminate the possibility of silent complicity as described above. On the other hand, if we hold that silent complicity is a real possibility for companies, we must expand our view on corporate obligation beyond the negative realm and at least contemplate corporate obligations also in the category of the duty to protect.

In order to determine under what circumstances corporations are indeed violating a positive duty to help protect (i.e., meet the first constitutive requirement for silent complicity), we must know something about the conditions and criteria that underlie moral duties in general. Such conditions generally get more extensive when moving from passive to active duties and from negative to positive ones.

Generally, for there to be a passive negative duty to do no harm, only one condition needs to be fulfilled, which is that an agent has some level of autonomy to act. It is against this background that the passive negative duty to do no harm is of general nature and of universal reach; it applies to everyone at the same time and to the same extent. I will refer to this as the criterion of voluntariness. Second, for a negative duty to become active there must be a morally significant connection between the respective agent and the human rights violation. In contrast to passive duties, active duties (negative or positive) are specific and dependent on the context and situation; they apply to particular agents to varying degrees and extent. However, for active duties to apply to some agents but not to others, there must be something that specifically links those agents to the human rights violations at stake. I will call this the connection criterion. For there to be a positive duty to help protect, these two conditions must be complemented with a third one; a positive duty to improve a given state of affairs presupposes that a duty-bearer has the power to exert influence on the situation in a positive way. Thus, I will refer to this as the criterion of influence/power. The first two conditions aim at the non-violation of human rights, which means that they can be justified on a deontological basis. The third condition, however, aims at the improvement of a given situation. Thus, its justification or plausibility requires at least some sensitivity to consequences (not, however, consequentialism). Let us analyze all three conditions in some more detail.

Voluntariness: Passive negative duties apply to all responsible individuals at all times and to the same extent; we all have the same duty to abstain from harming others. For any rational, adult human being this responsibility can only be mitigated or eliminated if the action causing harm is not freely chosen or if the harmful consequences are not foreseeable. Thus, moral responsibility, as opposed to mere causal responsibility, depends on autonomous and thus voluntary or intentional action. We can only be held morally responsible for actions we freely and willingly choose, 
but not for those over which we have no control or which we are forced to commit. As Iris Marion Young argued correctly:

If candidates for responsibility can demonstrate that their causal relation to the harm was not voluntary, that they were coerced or that they were in some other way not free, then their responsibility is usually mitigated if not dissolved. When the agents are causally and freely responsible, however, it is appropriate to blame them for the harmful circumstances. (Young 2003: 40)

We generally distinguish between two kinds of unfreedom, which tend to mitigate or resolve moral responsibility. First, our autonomy can be impaired internally due to mental or psychological conditions. In such cases, we may not be fully in control of our own actions. Second, there can be external restrictions for autonomous action. Such external restrictions may come in form of coercion, that is, by the use of force or credible threats, on the one hand, or as a lack of alternatives on the other. With regard to the latter case, whether or not we are able to act freely is frequently seen as a matter of having viable alternatives from which to choose (Gosepath 2004: 54-55). This condition is also known as the "principle of alternate possibilities."13 The viability of alternatives and thus the question whether or not action can be considered truly free, also depends on the normative burden or, in Kant's (1996: 19f.) words, "obstacles," which they present to us:

Subjectively, the degree to which an action can be imputed (imputabilitas) has to be assessed by the magnitude of the obstacles that had to be overcome.-The greater the natural obstacles (of sensibility) and the less the moral obstacle (of duty), so much the more merit is to be accounted for a good deed, as when, for example, at considerable self-sacrifice I rescue a complete stranger from great distress. (Kant 1996: 19)

Thus, for a course of action to be considered a viable option or alternative, the obstacles which it presents to the agent must not be unreasonably high in relation to the fundamentality of the moral obligation at stake. The more fundamental the obligation we are looking at, the less weight the argument of normative cost connected to fulfilling it will carry. Thus, in order to nullify moral responsibility for a harmful action in the category of passive negative duties, one would have to show that the normative cost of abstaining from that action greatly outweighed the negative obligation to do no harm. Considering the primacy of the do no harm principle, such attempts succeed only very rarely. Or, formulated differently, our obligation not to harm others holds even at considerable cost to ourselves. This is the case particularly where obligations as fundamental as the ones deriving from human rights are weighted against mere utilitarian considerations. This is not to say that there are no thinkable cases in which the normative burden of avoiding to do harm may be too high for a specific agent. Perhaps the most evident and intuitive example is that of harm committed in self-defense, that is, cases in which one's own life may be severely threatened. However, generally, normative burden considerations become more relevant and important when dealing with positive, rather than negative duties.

Connection: For there to be an active negative duty, voluntariness must be combined with connection. As pointed out earlier, silence turns into complicity only if, 
based on the perception of implicit endorsement or approval, it has a legitimizing or encouraging effect on the wrongdoing. This, it seems, presupposes a significant connection between the agent and the human rights violation. After all, the very claim that agents have an active duty to disassociate themselves from a particular human rights violation or its perpetrator already implies that there is an actual connection that links them to the violation in a morally relevant way. The crucial question is what qualifies connections as morally significant in this context of silent complicity. Generally, we can distinguish between two categories of connections: an agent can either be actively connected or passively connected to the violation. Active connection essentially means actual involvement, that is, the agent actively contributes to the violation of human rights committed by the primary perpetrator. However, such cases of active involvement belong to the category of direct complicity, which establishes a passive negative obligation to do no harm. In such cases, active involvement or contribution to the human rights violation is the problem, rather than the agent's silence. Hence, the connections that are relevant for silent complicity are of the passive kind. A passive connection as the Office of the High Commissioner for Human Rights (2004: 18; emphasis added) argues correctly, requires association, rather than involvement: "A company is complicit in human rights abuses if it authorises, tolerates, or knowingly ignores human rights abuses committed by an entity associated with it."

The most common and relevant kind of passive association is established through benefit. In other words, an agent may be linked to the human rights abuse by directly or indirectly benefitting from it. While benefit is often dealt with separately under the category of "beneficial complicity," it can serve as a condition also for the further going claim of silent complicity. ${ }^{14}$ However, benefit is not the only way a company can be associated with human rights violations. Such a connection can be established also through special relationships between the company and either the victims (e.g., employees) or the perpetrator. Moreover, the state may be perceived as acting on behalf or in the name of the company; alternatively, protecting a company's interests may be (part of) the actual reason for a host government to violate rights. For example, in 2005, soldiers from the Nigerian Joint Task Force opened fire on demonstrators who protested against Chevron for allegedly breaking an agreement to provide jobs and development for the local community in which it operated. Chevron may or may not have benefitted from the crack-down. Even in the absence of benefit, however, the evident link between the protesters and the corporation would be enough to establish a morally significant connection. A recent cover story by the New York Times about "one of the authorities' newest tactics for quelling dissent" in Russia provides a second example (Levy 2010b: 1, 15). Russian police allegedly engaged in a systematic campaign to confiscate the computers of government-critical advocacy groups under the pretense that they contained unlicensed Microsoft software. What was particularly concerning about the raids was that they rarely if ever targeted pro-government groups and that computers were seized even in cases where they did not contain illegal software, giving rise to the suspicion that these investigations were politically motivated. At least in some of these incidents Russian authorities claimed to be acting on behalf and in the name 
of Microsoft, which prompted some groups to argue that "Microsoft needed to issue a categorical public statement disavowing these tactics." In such cases, the company indeed seems to have a duty to disassociate itself from the government's actions; silence will likely be perceived as support or endorsement, even if the company never gave its explicit approval for the human rights violation. ${ }^{15}$ In response to the cover story run by the New York Times, Microsoft not only distanced itself from the stance of the Russian authorities and asked them to drop pending inquiries, but distributed free software licences to more than 500,000 advocacy groups, independent media outlets, and NGOs in 12 countries with repressive governments, which effectively eliminated the legal basis for such investigations (Levy 2010a: 6).

Influence/Power: While voluntariness and connection are necessary conditions for there to be a moral obligation for a company to speak out against human rights abuse, they merely establish a negative obligation for the company, that is, an obligation to disassociate itself from the perpetrator and its harmful actions. However, on their own, these two conditions are insufficient to establish a positive duty to speak out to help protect the victims. For the company to have a positive obligation to speak out, it must be in a position to exert pressure or influence for the purpose of improving the situation of the victims.

As seen above, the condition of voluntariness derives from the general philosophical principle of "ought implies can." Attaching moral blame to a specific deed or action committed by an agent presupposes that the respective agent has the possibility or ability to act otherwise, i.e., that he voluntarily chooses to act the way he does. In the realm of positive obligations, this principle of "ought implies can" must be reinterpreted in a consequence-sensitive way. For an agent to have positive obligations he must have the capacity or potential, that is, the alternative or option to influence the situation in a positive way. This ability to have a positive impact by influencing the behavior of an actual or potential perpetrator, is what we commonly associate with the concept of power (see, e.g., Strange 1996: 17). ${ }^{16}$

Hence, for a corporation to have a positive duty to address human rights violations with the appropriate authorities in a host country its opposition to and condemnation of the human rights violation must matter to the actual or potential perpetrator. It must be important enough to raise a real possibly that the perpetrator will reconsider and change his or her problematic actions or policies. ${ }^{17}$ Here is where the discussion of the normative burden becomes relevant. For there to be a positive obligation to confront a potential or actual perpetrator, the agent's normative burden, for example, in form of retaliation by the perpetrator, must not be prohibitive.

While silent complicity presupposes the existence of a positive duty to come to the victims' assistance, failure to speak out does not necessarily and by itself signify that a corporation is silently complicit. To be silently complicit, failure to speak up must help to legitimize the violation or have an encouraging effect on the perpetrator. This constitutes the "legitimization requirement" which is the fourth and final condition for silent complicity. 


\section{ASSESSING THE "LEGITIMIZATION REQUIREMENT": SOCIAL OR POLITICAL STATUS}

The legitimization requirement consists of two elements. First, an agent's silence must imply implicit endorsement of the human rights violation. Second, this implied endorsement must serve to legitimize or encourage the violation. The implied endorsement derives from the combination of voluntariness, connection, and power as discussed above. Hence, an agent who is connected to the human rights violation and would be in a sufficiently powerful position to speak out against it can be perceived as endorsing it, if she chooses not to speak out. In order for an agent's implied endorsement to add legitimacy to the incident, her stance on the issue must carry some weight in the public perception. For this to be the case, the agent must be of a certain status or standing. This may involve high social regard and prestige. It may imply that the agent is representative of society or a relevant subset thereof. In the so-called companion report, SRSG John Ruggie makes a similar claim by evoking insights from criminal law:

In international criminal law, individuals have been convicted of aiding and abetting international crimes when they were silently present at the scene of a crime or in the vicinity of a crime. However, in these cases presence was only one factor that led to a finding that the individuals' acts or omissions had a legitimizing or encouraging effect on the crime in the specific context, and all of the accused also had some form of superior status. (United Nations 2008a: 12; emphasis added)

There is little doubt that corporations can acquire the kind of social status that is necessary to meet the legitimization requirement, both in principle and in practice. Branding has turned corporations like Apple or Nike into icons not only of Western consumerist societies but on a worldwide scale. Subsequently—and not surprisingly - the management of prestige and reputation has become a core concern especially of large, global businesses today. In her book No Logo (Klein 2000), Naomi Klein helps us understand corporate brands as one of the main sources of corporations' social influence and power in today's day and age. ${ }^{18}$ This phenomenon is not entirely new; by 1946, Peter Drucker was speaking of the large American corporation as an "institution which sets the standard for the way of life and the mode of living of our citizens; which leads, molds and directs; which determines our perspective on our own society; around which crystallize our social problems and to which we look for their solutions" (Drucker 1993: 6). Consistent with this assessment, John Micklethwait and Adrian Wooldridge propose that corporations have been at the forefront of all significant social changes since at least the middle of the nineteenth century, not merely "as a matter of churning out society-changing products, like the Model T or Microsoft Word, but of changing the way that people behave-by disrupting old social orders, by dictating the pace of daily life" (Micklethwait and Wooldridge 2003: 181). Social life everywhere, as Charles Derber concludes, has turned "into an expression of global corporate values" (Derber 2002: 72). One does not need to endorse Derber's perception of all-out corpocratic rule to make sense of 
corporations as socially powerful institutions and thus to understand their capacity to legitimize human rights violations overtly or implicitly.

The question of political status is closely intertwined with Drucker's observation and has recently been addressed both by the broader discussion on global governance as well as that on business ethics and corporate responsibility. While scholars concerned with global governance have realized the relevance especially of multinational corporations for the regulatory structure of the global political economy (see, e.g., Cutler 1999; Hall and Biersteker 2002; Kobrin 2009), business ethicists have started to theorize the political nature of the corporation and to understand political engagement as a relevant aspect of corporate responsibility (see, e.g., Ulrich 2001, 2008; Matten and Crane 2005; Scherer, Palazzo, and Baumann 2006; Scherer and Palazzo 2007; Scherer, Palazzo, and Matten 2009).

The literature on global governance has made important contributions toward making the growing political status of multinational corporations more visible; in particular, it has stressed the existence and importance of "private political authority" (Kobrin 2009), which, according to A. Claire Cutler, has long been obscured systematically by the basic assumptions of today's economic liberalism:

[L]iberalism obscures the political significance of private economic power through the association of authority with the public sphere and its disassociation with private activities. Indeed liberalism renders private authority an impossibility by creating the distinction between public and private activities and locating the "right to rule" or authority squarely in the public sphere.... [T] he public/private distinction renders the political significance of transnational and multinational corporations invisible. (Cutler 1999: 73)

Contributions that attempt to correct this blind spot of conventional economic liberalism and to highlight the new political role and stature of multinational corporations commonly stress the profound transformations at the global level induced by the "denationalization of capital and the disembedding of commercial activities from governmental and social controls" (Cutler 1999: 73). Concordantly, the emergence of what is believed to amount to a "post-Westphalian transition world order" (Kobrin 2009: 350) puts the basic assumptions of state-centrism into question. It blurs the line between public and private spheres, whose neat separation is criticized by Cutler. It increases ambiguity around borders and jurisdictions (Kobrin 2009: 350), and, as a result, leads to the fragmentation or reconfiguration of political authority (Kobrin 2009: 350; Cutler 1999: 73). Within and through this process, transnational companies emerge as "actors with significant power, influence and authority in the international political system" (Kobrin 2009: 350).

As previous commentary points out, transnational companies today are involved at all stages of public policy formation, from participating in negotiations all the way to setting standards, supplying public goods, and even on occasion the writing of legislation. As a result, they increasingly find themselves confronted with direct public demands that are not communicated via market signals nor imposed through government regulation (see Hertz 2001: 112; Wettstein, 2009: 243). Accordingly, such demands cannot be dealt with by mere compliance with state-imposed laws and regulations or with business savvy (for demands mediated by the market mechanism) 
but must be directly engaged with (see Scherer and Palazzo 2007). As a result of these developments, the modern corporation has acquired both political authority and political responsibility.

Political responsibility, as the late Iris Marion Young (2004) showed so convincingly, is to be understood as positive responsibility of an inherently communicative nature. Young points out that it is "political in these senses that acting on my responsibilities involves joining with others in a public discourse where we try to persuade one another about courses of collective action that will contribute to ameliorating the problem" (Young 2004: 380). Reflecting on this notion of political responsibility, Scherer and Palazzo (2007: 1109-11) redefine corporate responsibility in deliberative terms. Building on these insights, a duty to publicly speak out against human rights abuse and to address the issue with the appropriate authorities seems indeed prototypical for this "new political responsibility of the business firm" (Scherer and Palazzo 2007: 1109).

In sum, silent complicity occurs if all four conditions as outlined in the previous two sections are satisfied. In such cases, the corporation can be identified as having a positive obligation to speak out to help protect human rights.

\section{INNOCENT BYSTANDER OR SILENTLY COMPLICIT?: \\ THE EXECUTION OF KEN SARO-WIWA AND SHELL'S “ECOLOGICAL WAR” IN THE NIGER DELTA}

On Tuesday, 31 October 1995, Nigerian playwright and minority-rights activist Ken Saro-Wiwa, along with eight of his followers, were sentenced to death by a specially convened, "hand-picked" (Duodu 1995: 24) tribunal of the Abacha regime in Nigeria for inciting the murder of four conservative, pro-government Ogoni chiefs. The four Ogoni chiefs were rounded up and killed by a rioting mob on 21 May 1994. On 10 November 1995, just ten days after the sentence was passed, Saro-Wiwa and his friends were executed while the world watched in outrage.

At the time of his arrest, Ken Saro-Wiwa and his activist group "Movement for the Survival of the Ogoni People" (MOSOP) were spearheading widespread protests against exploitation and environmental degradation by oil companies in the Ogoni land. Protests against the environmental destruction caused by oil companies had been growing throughout the Niger Delta since the 1970s. ${ }^{19}$ When the protests grew bigger and more numerous in the early 1990s, the government started to repress them violently—often at the specific request of Shell (Rowell 1995: 6; Rowell 1996: 295). Growing tension between Shell and the indigenous people in the Niger Delta led to increasing numbers of increasingly violent protests. The most devastating of these protests occurred in January 1993, when, at the dawn of the UN Year of Indigenous Peoples, the largest peaceful rally against oil companies to that point in time was silenced violently by government forces, resulting in the destruction of 27 villages, displacing 80,000 Ogoni villagers, and leaving some 2000 people dead (Rowell 1996: 297). As the struggle evolved, the Ogoni people became the "vanguard movement for adequate compensation and ecological self-determination" in the Niger Delta and Shell became the symbol of their oppression (Rowell 1995: 
6). Saro-Wiwa was the driving force behind the Ogoni movement; "No other person in Nigeria," as one member of the Nigerian Civil Liberties Organisation put it, "can get 100,000 people on the streets" (quoted in Rowell 1996: 298).

The murder of the four chiefs provided the Nigerian government with an opportunity to arrest Saro-Wiwa and eight other leaders of his organization. The charges against Saro-Wiwa and his colleagues were anything but uncontroversial. It was even suggested that the Nigerian government itself was involved in provoking the murders as a justification for stronger military presence in the region. Not only was Saro-Wiwa "miles away" when the murders took place, but he was, in fact, under military escort (e.g., Rowell 1996: 303-05). Key witnesses admitted that they had been bribed to provide false evidence (Sweeney and Duodu 1995: 24; Rowell 1996: 308 ) and the tribunal, which was controlled by the military, was denounced as illegitimate by the international community due to blatant violations of international fair trial standards and a lack of respect for due process. The British government condemned the trial as "judicial murder" (Rowell 1996: 1).

The international protests did not remain limited to the Nigerian government. Shell too came under attack for idly standing by while the tragedy unfolded. Shell was accused of not using its influence in Nigeria to stop the execution, the torturing of protesters, and the violent crack-down of demonstrations. In other words, Shell was seen as being silently complicit by violating a positive duty to help protect them against the human rights violations of the Abacha junta. Our analysis now provides a tool with which to assess the validity of this claim. For Shell to be silently complicit, the two qualified conditions underlying the omission requirement (i.e., connection and influence/power $)^{20}$ as well as the status condition underlying the legitimization requirement all need to have been met.

Connection: The connection between Shell and Ken Saro-Wiwa's and the roughly 2000 other Ogoni deaths is undisputed. The uprising of the Ogoni people was a direct response to Shell's operations in the Niger Delta; their protests were directly aimed at Shell. In some instances the police forces that put the demonstrations down were requested by Shell. Even when they were not requested, the suppression of large scale protests benefitted Shell and secured the continuation of its operations. In his closing statement to the tribunal, Ken Saro-Wiwa explicitly addressed Shell's role and connection to the incidence:

I repeat that we all stand before history. I and my colleagues are not the only ones on trial. Shell is on trial here, and it is as well that it is represented by counsel said to be holding a watching brief. The company has, indeed, ducked this particular trial, but its day will surely come and the lessons learned here may prove useful to it, for there is no doubt in my mind that the ecological war the company has waged in the delta will be called to question sooner than later and the crimes of that war be duly punished. The crime of the company's dirty wars against the Ogoni people will also be punished. ${ }^{21}$

Shell was both the main cause for the formation of the Ogoni protests and it was the main reason for the violent crack down. Shell was, by every definition of the word, linked to the execution of Ken Saro-Wiwa and his friends in a morally significant way. 
Influence/Power: For Shell to have a positive duty to help protect and thus to speak out against the trial and to put pressure on the Nigerian government, their connection to the incidence must come with a position of influence or power. While the degree of Shell's real influence at the time ultimately is subject to speculation, most of the evidence and, as we will see shortly, also Shell's own assessment of its influence in Nigeria suggest that this condition too was met. Shell's position in Nigeria was and still is exceptionally powerful. The military government's power was dependent on the foreign earnings generated by oil and Shell was by far the major oil producer not only in the area but in the whole country (Babade 1995). At the time of Saro-Wiwa's execution, Shell produced roughly half of Nigeria's crude oil output (Reuters 1995). As a result, Shell's power and influence was by any measure considerable. ${ }^{22}$ Thus, Andrew Rowell observes that Shell's position in Nigeria was "both powerful and unique." Quoting an anonymous Ogoni activist, he says: "With such an illegitimate political system, each bunch of unelected military rulers that comes into power, simply dances to the tune of this company. ... Shell is in the position to dictate, because Nigeria is economically and politically weak" (Rowell 1996: 289).

Status: At the time of the execution Shell enjoyed the prestige of a company with global brand recognition. In the mid-1990s, Shell was the world's biggest oil company not owned by a government, it was producing 3 percent of the world's crude oil and 4 percent of its natural gas. It was the world's only private company to rank among the top ten biggest holders of oil and gas reserves (Prest 1995: 4). Its influence both in Nigeria and globally was substantial. It was without doubt a company that led, molded, and directed, a company that disrupted old social orders and dictated the pace of daily life in Nigeria and the Niger Delta. The very protests that erupted first in Nigeria against Shell's environmental record and later on an international scale against Shell's way of handling the turmoil in Nigeria underscore Shell's standing relative to society at large. Furthermore, they are a case in point regarding the politicization of corporations and the subsequent call for deliberative public engagement. In light of the worldwide attention that the Shell case received, it seems that it would at least be difficult to argue that the company lacked the status necessary to be implicated with silent complicity.

Based on such assessments there certainly is a case to be made for Shell's silent complicity in Saro-Wiwa's execution. Many commentators believed and continue to believe that Shell was in a position to speak out against the trial. Saro-Wiwa's brother, Owens Wiwa goes so far as to claim that if Shell "had threatened to withdraw from Nigeria unless Ken was released, he would have been alive today. There is no question of that" (Owens Wiwa quoted in Ghazi 1995: 1). Andrew Rowell's conclusions even reach beyond the specific incident around Saro-Wiwa: "[S]uch is the economic strength of the company that few people in Nigeria or Britain doubt that it could have stopped the conflict outright-or at least stopped the use of excessive force against demonstrations" (Rowell 1995: 6). Shell was well aware of its powerful position in the country and its potential to turn the events around. In fact, as The Observer reported nine days after Saro-Wiwa's execution, Brian Anderson, who was head of Shell Nigeria at the time, had in fact offered to Owens Wiwa to use Shell's 
influence with Nigeria's military regime to try to free his brother; however, his offer was conditional on the Ogoni leaders calling off any global protests against Shell. This bargain, irrespective of its questionable ethical quality, was unattainable for Wiwa: "Even if I had wanted to, I didn't have the power to control the international environmental protests."(Owens Wiwa quoted in Ghazi 1995: 1)

Shell defended its position of inactivity against the growing public outrage. The company's official position was that it would be "dangerous and wrong" for Shell to "intervene and use its perceived 'influence' to have the judgment overturned." "A commercial organization like Shell," as they claimed further, "cannot and must never interfere with the legal processes of any sovereign state." ${ }^{23}$ A Shell manager reportedly stated in 1996:

I am afraid I cannot comment on the issue of the Ogoni 9, the tribunal and the hanging. This country has certain rules and regulations on how trials can take place. Those are the rules of Nigeria. Nigeria makes its rules and it is not for private companies like us to comment on such processes in the country. ${ }^{24}$

These arguments appear at least hypocritical in light of Shell's secret proposal to Owens Wiwa. However, they reflect more than a subjective assessment of the situation; they represent a line of counter-argumentation that is frequently evoked in connection with corporate political activity. Such counter-arguments are based on two core assumptions. First, Shell's statements assume a neutral, apolitical role for corporations. Silence is perceived as neutrality, while speaking out denotes illegitimate political interference by the corporation. Second, corporations engaging in such political activity and exerting influence and pressure on host governments are perceived to illegitimately interfere with the sovereignty of the respective government. In the next section I examine both these propositions.

\section{TWO OBJECTIONS: \\ CORPORATE NEUTRALITY AND ILLEGITIMATE INTERFERENCE}

The first objection outlined above only warrants a short response. Shell defended its silence as neutrality and implicitly presented itself as an apolitical institution. It is the very purpose of this paper to show that silence is not always neutral but can, in fact, denote a form of complicity. Shell was intimately connected to the human rights violation taking place in Nigeria. Taking a neutral position in such a situation is problematic in itself; it is a calculated political strategy disguised as moral virtue. Shell's connection to the human rights violations combined with its power and status turned its silence into moral approval. Jenik Radon rightly points out in regard to powerful corporations in the extractive sector: "Even if they do nothing, remain silent, they are effectively acting, having an impact" (Radon 2005). Thus, Shell's contention that silence was required because speaking out would be a public and political and thus an improper act was inherently flawed. Shell's silence was as much a politically relevant act as explicit opposition would have been. Shell had a choice to make; it could speak out in favor of human rights or keep silent in support of the perpetrator. Unfortunately, it chose the latter alternative. 
Let us turn to the second part of the objection. Speaking out to help protect human rights, so the argument of opponents goes, denotes illegitimate interference with a host government's sovereignty. This argument warrants three specific responses. First, corporations rarely hesitate to make themselves heard when economic rules and regulations affect their business projections; pushing for tax breaks, subsidies in the millions, or exemptions from restricting regulations has turned into a regular and, in fact, lucrative part of doing business. This kind of corporate political activity is rarely described as interference with the sovereignty of the countries in which they are operating. However, such policies and regulations (or lack thereof) for which corporations tend to push are by no means neutral in regard to their impact on human rights either. Hsieh (2009: 267), who has recently addressed the interference question in connection with a possible corporate responsibility to promote just institutions in host countries ${ }^{25}$ is quite right in arguing that "if the objection is that MNEs should not be involved in politics, then this would rule out any form of political involvement by MNEs." In light of the political involvement of multinational corporations outlined above, such a scenario seems more and more unlikely to begin with.

Second, it seems all too easy to dismiss the call for corporate action to contribute to the protection of human rights as a violation of state sovereignty without having a discussion about the validity of sovereignty as a moral value or political concept beforehand. After all, the moral value of state sovereignty as a concept worth defending can at best be derivative. State sovereignty or autonomy is not valuable in and of itself but depends on its consistency with and contribution to more basic principles of justice (Beitz, 1999: 69). The importance of protecting state sovereignty derives from the claim for autonomy and self-determination of human beings as the ultimate unit of moral concern. Thus, if state sovereignty is in direct conflict with the claim for justice and autonomy for human beings, that is, if it serves to protect perpetrators rather than their victims, the justification of upholding it seems questionable. Speaking out in defense of human rights, as also Sir Geoffrey Chandler argued, is a "wholly legitimate role" for companies. "It is not interference in domestic politics, an argument that companies have used as an escape route in the past" (Chandler, 1999: 43).

This leaves, third, the possibility of denying the universal validity of global justice and human rights at the outset. However, it seems peculiar how this argument can be reconciled with the converse assumption of global absoluteness of state sovereignty which has to be respected and protected seemingly at all cost. It seems unclear what this absoluteness is based on if the validity even of the most fundamental human rights is denied at the same time. Thus at the heart of this argument is a confusion of values which gets more evident and troubling the more egregious the cases of rights violations at stake. As its ultimate consequence, it would suggest illegitimacy even of speaking out against mass murder and genocide in order to uphold the sovereignty and autonomy of the perpetrator.

\section{CONCLUSION}

Taking seriously the concerns of those who fear that a positive obligation of corporations to speak out against human rights is a first step toward corporate tyranny, this 
concluding part of the analysis proposes four safeguards that aim at ensuring that such corporate political activity contributes to and does not undermine the public interest. The proposed safeguards may not be and are not meant to be exhaustive, but are to be understood as connecting points for further research. I will relate all four safeguards back to the Shell example discussed above.

Scale of Human Rights Violations: there is room for interpretation even when it comes to the violation of human rights. Therefore, we might want to limit corporations' positive obligation to speak out to cases of severe, systematic, and ongoing human rights violations, that is, to those human rights abuses whose condemnation is widely shared. This criterion becomes more important the less visible and direct a corporation's connection to the rights violation. As previous discussion has demonstrated, the condition of severity was met in the Saro-Wiwa case. The violations of human rights were ongoing and systematic, and they were committed at a scale that led Nigerian writer and Nobel Laureate Wole Soyinka (1996) to speak of "ethnic cleansing" in the Ogoni region.

Responsiveness: connected to the claim made above, we do not want companies to turn into self-righteous moral arbiters of our global community (Chandler, 2000: 5). Rather we want them to respond effectively to the concerns of the global public and its institutions and especially to those whose rights are spurned. Thus, the yardstick for a corporate obligation to speak out is a forming global consensus that action, rather than inaction is needed. This can manifest itself as formal resolutions against an oppressive regime or in form of widespread protests. This condition too, was met in the Shell incidence. The Ogoni movement repeatedly called for Shell to address the issue, to denounce Saro-Wiwa's arrest, and to use its influence to get him released. Governments and scores of concerned citizens around the world denounced the trial against Saro-Wiwa as flawed and unfair and the oppression of the Ogoni people as unacceptable.

Collaboration: We do not want corporations to act alone but ask them to consult and collaborate with other institutions, with a view to requesting and receiving assistance and advice in navigating sensitive moral issues in ways designed to ensure their interventions are legitimate and effective. Such institutions can be NGOs, activist groups to whose pressure corporations are responding, government agencies, international and supranational organizations, as well as other companies which find themselves in similar situations. What is more, where corporations may have little influence acting alone, they may nevertheless find themselves in positions of substantial leverage once they collaborate with other players. There is little doubt that Shell did have the authority and leverage to exert influence over the Nigerian government. Nevertheless its doubts about the legitimacy of speaking out could have been eased through collaboration with local Ogoni rights groups, not least SaroWiwa's own MOSOP, and with foreign governments and NGOs such as Human Rights Watch, which repeatedly pressed Shell to oppose the government's human rights abuses at that time.

Publicness: Corporate political action must be paired with accountability. Accountability, however, requires some degree of transparency. Thus, corporations accused of silent complicity must take a public stance against the violation of human 
rights. In other words, "quiet diplomacy" might do little to divert the accusation of silent complicity (Clapham and Jerbi, 2001: 349); it might even lead to increased suspicion about the harmful collusion between government and corporations. I am not advocating for full transparency of such interaction; however, corporations must make public the information that they are, in fact, engaging in such interaction and they must be transparent about their underlying intentions and the goals they are trying to achieve with it. Ensuring that the public is informed about its political activity means that it is open and subject to public deliberation and scrutiny. The Shell case underlines the importance of this point. Shell's alleged silent diplomacy contributed to further obscuring the company's position and its potential involvement into the human rights abuses in the region rather than to communicating clearly and openly what the company's stance on the issue really was.

\section{NOTES}

I would like to thank three anonymous reviewers and the editors of this special issue for their help and guidance in getting this manuscript published. I am particularly grateful to "Reviewer 2" and especially to Wes Cragg for engaging so very thoroughly with this paper and for the thoughtful input they provided regarding the form and basic shape of my argument.

1. This may be the reason underlying Hoffman and McNulty's (2009: 546) recent observation that "critics of globalization have missed the mark by focusing on obvious examples of corporate malfeasance while remaining relatively mute with respects to the more pervasive and significant problem, which is business's complicity in providing direct or indirect support to authoritarian regimes involved in human rights abuses." Furthermore, existing responses to corporate complicity, as Hoffman and McNulty (2009: 548) point out, have been characterized by a "general lack of consistency."

2. I will refer to this duty as a "duty to help protect" in order to ensure consistency with the terminology of the tripartite framework used by the SRSG (see United Nations 2008a, b). Alternatively, the duty to speak out as it is outlined in this paper may also be interpreted as a duty to promote or a duty to "promote respect" (Cragg 2004: 117) for human rights. In fact, in his 2010 report, UN Special Representative Ruggie also refers to the task of "promoting respect" for human rights on several occasions within the section on the state's duty to protect (United Nations 2010: 5, 7). Perhaps more important than the terminology used is that the corporate duty advanced in this paper (whatever we may ultimately call it) is positive and thus goes beyond a mere duty to respect human rights.

3. George Brenkert (2009: 459) has recently added the category of "obedient complicity." Obedient complicity refers to businesses engaging "in actions mandated by a state that significantly and knowingly violate human rights," which might not violate human rights if undertaken by the company on its own. Brenkert refers to the specific case of Google's compliance with China's censorship laws as an example. The concept of obedient complicity is closely related to the notion of "structural complicity," which I have used and defined elsewhere (see Wettstein, 2009: 304-05).

4. Note that complicity presupposes an actual contribution (active or passive) by the corporation to the human rights violation. While this contribution does not need to be indispensible, it must be substantial to amount to actual complicity (see, e.g., Ramasastry 2002: 150). This is why the perception of the corporation's mere endorsement or approval of the abuse is not sufficient to ground an accusation of complicity. While we can justifiably blame someone for endorsing and approving of a harmful practice, this endorsement must have a substantial effect on the human rights violation or the perpetrator in order to amount to actual complicity. This is the case if this endorsement can be perceived as legitimizing or encouraging the human rights violation or the perpetrator.

5. Beneficial complicity, in most cases, denotes a moral failure based on omission as well. Exceptions are cases in which corporations actively and deliberately exploit the situation for their own benefit.

6. http://www.unglobalcompact.org/AboutTheGC/TheTenPrinciples/principle2.html. 
7. See, e.g., Hsieh (2009: 253), who attempts to reformulate positive duties of corporations in negative terms in order to avoid said controversy. The same reasoning has been used also by Thomas Pogge (2002: 198). See Wettstein 2010 for a counter-argument to this position.

8. I would like thank Tom Campbell for alerting me to the possibility of passive positive obligations. Such obligations would have to be framed as a duty to abstain from certain actions in order let more good happen. Thus, what distinguishes such a duty from a passive negative duty is that interfering (i.e., acting) does not produce any harm, but merely prevents something good from happening. Hence, the question at the core of this scenario would be whether or not we do have an actual duty to let more good happen. This seems to be the case only in consequentialist/utilitarian ethics. It is questionable, however, in merely consequence-sensitive ethics, as it is the basis of this paper.

9. Shue (1996: 52) uses a slightly different terminology; he speaks of duties to avoid depriving, duties to protect from deprivation, and duties to aid the deprived. This framework has been adopted also by Professor John Ruggie (see, e.g., United Nations 2008b). Ruggie speaks of the duty to respect, the duty to protect, and access to remedies.

10. Similarly, Peter Frankental and Frances House (2000: 11) claim that corporations should "raise human rights concerns with government authorities either unilaterally or collectively with other companies."

11. A public condemnation alone could be framed as an active obligation of the negative kind and would serve the mere purpose of refuting the suspicion of a company's supportive stance toward the perpetrator; it would not include an expectation that speaking out assists or contributes to the protection of the victims in any way. Such an interpretation of the duty to speak out seems incomplete especially if conditions 3 (influence/power) and 4 (status) are met. In that case, a mere public condemnation is never enough to entirely diffuse the accusation of silent complicity. There are two reasons for this: a) powerful corporations that merely issue a public condemnation without actually doing anything to prevent human rights abuses to occur in their sphere of influence will likely be perceived as insincere or even hypocritical by the wider public, that is, as not walking the talk (or alternatively as not putting the money where their mouth is). Granted that by issuing a public condemnation they would formally disassociate themselves from the abuse and thus eliminate condition 2 in a narrow sense, but b) the effect of legitimization and encouragement in which the accusation of silent complicity is ultimately grounded would likely persist; in fact, a perpetrator who is faced with a situation where powerful actors disapprove of its stance but do not act on their disapproval might derive similar or even increased encouragement to continue the abuse. Thus, for a corporation that fulfils both the power and the status condition, the very act of disassociation must be interpreted as consisting of more than a mere public condemnation.

12. Ruggie does state that under certain circumstances corporations may have additional responsibilities; however, he limits these circumstances to cases in which corporations perform specific public functions or in which they have undertaken particular voluntary commitments (see United Nations 2008b: 9).

13. The requirement that moral responsibility presupposes an agent's ability to act freely is reflected in the principle "ought implies can." David Widerker (1991) and later David Copp (1997, 2008) confirmed the logic of the argument put forth here by showing that the Principle of Alternate Possibilities can be derived from the "ought implies can" principle. The Principle of Alternate Possibilities was famously refuted by Harry Frankfurt (1969).

14. Note that Anthony Ewing (2004: 39; emphasis added) argues that we may speak of silent complicity only if "companies remain silent in the face of human rights abuse committed by others that is of no particular benefit to the company." On the other hand, his definition of beneficial complicity clearly includes elements also of silent complicity: "A company is beneficially complicit if it tolerates or knowingly ignores the human rights violations of one of its business partners, committed in furtherance of their common business objectives." A more convincing way of dealing with these two forms of complicity is to acknowledge that, from a moral standpoint, we are dealing with two separate reasons or bases for moral blame, which, however, often - though not always—occur interdependently and at the same time.

15. Note that while the perception of endorsement is enough to trigger an active negative duty to disassociate oneself from the abuse, it is not enough to ground an actual accusation of silent complicity; for endorsement to turn into complicity it must have a legitimizing or encouraging effect on the abuse.

16. This insight seems to inform also Campbell's (2006: 262) argument for a corporate duty to put pressure on abusive host governments: "Yet because they are in a position to bring economic pressure to bear on host governments it is arguable that MNCs have a moral duty to do so in the absence of political solutions and in preference to military ones." 
17. A similar claim underlies Santoro's (2009: 14-17; Santoro 2010: 290-92) “'fair share' theory of corporate responsibility for human rights." Santoro argues that the extent to which corporations can reasonably be held responsible for remedying human rights violations, in which they have played no direct or indirect role, depends on the "potential effectiveness of the corporation in promoting human rights (the greater chance of being effective, the stronger the duty)" (Santoro 2009: 16). In addition to effectiveness as a criterion Santoro (2009: 16; 2010: 292) outlines two more conditions to be met for such a responsibility to apply to corporations. The two conditions closely resemble the ones outlined in this contribution: the first one concerns the relationship of the company to the human rights victims. The stronger such a relationship, the stronger is the corporation's responsibility. In comparison to Santoro's condition, the connection criterion outlined here is broader and includes relations not only to the victims, but also to the perpetrator. The third of Santoro's conditions (with "potential effectiveness" being the second) is a corporation's "capacity to withstand economic retaliation or to absorb the costs of an action" (Santoro 2010: 292). This condition aligns with my elaborations on the "normative burden."

18. Status, both social and political, has much to do with power and is closely related to the power condition discussed in the previous section. However, the two should not be confused; while the power condition specifically deals with power and influence over the perpetrator, the power notion underlying the status condition can, but does not have to be defined in relation to the perpetrator. Thus, in most cases we are dealing with two separate power notions: one specifying the corporation's potential to influence the perpetrator and one constituting or deriving from its general social or political status.

19. For an account of the nature and extent of the environmental damage caused by oil operations in the Niger Delta, one of the most fragile and endangered ecosystems on the planet, see Rowell (1996: 288-97). The practices used by Shell and other oil companies in the Niger Delta were widely regarded as unacceptable and unthinkable in Europe or America (Rowell 1996: 291).

20. I will limit my elaborations to the two qualified conditions (connection and influence/power), assuming that the first, general condition of voluntariness and thus Shell's general obligation to do no harm was fulfilled. While the financial hit resulting from a withdrawal of Shell from Nigeria would undoubtedly have been significant, it is unlikely that it would have threatened the very existence of the company. Given my above assessment that especially utility considerations are frequently trumped by human rights claims, it is safe to say that the company did have the option and thus the obligation to avoid its potential complicity.

21. http://archive.greenpeace.org/comms/ken/state.html.

22. The fact that Shell escaped largely unscathed when, in 1979, Nigeria nationalized the assets of BP (Prest 1995: 4) may serve as an additional indicator of Shell's status vis-à-vis the Nigerian government.

23. "Clear Thinking in Troubled Times," SPDC Press Statement, 31 October 1995. Quoted in Human Rights Watch 1999.

24. E. Imomoh, General Manager, Eastern Division, Shell Petroleum. On Africa Express, Channel 4 TV, UK (18 April 1996). Quoted in Avery 2000: 22.

25. Note that Hsieh explicitly excludes cases of complicity from his analysis. Nevertheless his elaborations on corporate interference with state sovereignty hold relevance also for this paper.

\section{REFERENCES}

Arnold, D. 2010. "Transnational Corporations and the Duty to Respect Basic Human Rights," Business Ethics Quarterly 20(3): 371-99.

Avery, C. L. 2000. Business and Human Rights in a Time of Change (London: Amnesty International UK).

Babade, N. 1995. "Nigerian Activist Saro-Wiwa Sentenced to Hang," Reuters News (October 31).

Beitz, C. R. 1999. Political Theory and International Relations (Princeton, N.J.: Princeton University Press).

Brenkert, G. G. 2009. "Google, Human Rights, and Moral Compromise," Journal of Business Ethics 85(4): 453-78. 
Campbell, T. 2006. "A Human Rights Approach to Developing Voluntary Codes of Conduct for Multinational Corporations," Business Ethics Quarterly 16(2): 255-69.

Chandler, G. 1999. "Keynote Address: Crafting a Human Rights Agenda for Business," in Human Rights Standards and the Responsibility of Transnational Corporations, ed. M. K. Addo, 39-45 (The Hague: Kluwer Law International). 2000. "Foreword," in Human Rights—Is It Any of Your Business?, ed. P. Frankental and F. House, 5 (London: Amnesty International UK and The Prince of Wales Business Leaders Forum).

Clapham, A. 2006. Human Rights Obligations of Non-State Actors (Oxford: Oxford University Press).

Clapham, A., and S. Jerbi. 2001. "Categories of Corporate Complicity in Human Rights Abuses," Hastings International and Comparative Law Review 24: 339-50.

Copp, D. 1997. "Defending the Principle of Alternate Possibilities: Blameworthiness and Moral Responsibility," Nous 31: 441-56.

.2008. "'Ought' Implies 'Can' and the Derivation of the Principle of Alternate Possibilities," Analysis 68(1): 67-75.

Cragg, W. 2004. "Human Rights, Globalization and the Modern Stakeholder Corporation," in Human Rights and the Moral Responsibilities of Corporate and Public Sector Organisations, ed. T. Campbell and S. Miller, 105-28 (Dordrecht: Kluwer Academic Publishers).

. 2010. "Business and Human Rights: A Principle And Value-Based Analysis," in The Oxford Handbook of Business Ethics, ed. G. G. Brenkert and T. L. Beauchamp, 267-304 (Oxford: Oxford University Press).

Cutler, A. C. 1999. "Locating 'Authority' in the Global Political Economy," International Studies Quarterly 43(1): 59-81.

Derber, C. 2002. People Before Profit: The New Globalization in an Age of Terror, Big Money, and Economic Crisis (New York: St. Martin's Griffin).

Drucker, P. F. 1993. Concept of the Corporation (New Brunswick, N.J.: London: Transaction Publishers).

Duodu, C. 1995. "The Playwright, the Doctor, the Unionist and their President," The Observer (November 5): 24.

Ewing, A. P. 2004. "Understanding the Global Compact Human Rights Principles," in Embedding Human Rights in Business Practice, ed. UN Global Compact Office and OHCHR, 29-42 (New York: UN Global Compact Office. Available online at http:// www.unglobalcompact.org/docs/issues_doc/human_rights/Resources/embedding.pdf.

Frankental, P., and F. House, eds. 2000. Human Rights—Is It Any of Your Business? London: Amnesty International UK and The Prince of Wales Business Leaders Forum.

Frankfurt, H. 1969. "Alternate Possibilities and Moral Responsibility," Journal of Philosophy 66: 828-39.

Ghazi, P. 1995. "Shell Refused to Help Saro-Wiwa Unless Protests Called Off," The Observer (November 19): 1.

Gosepath, S. 2004. Gleiche Gerechtigkeit: Grundlagen eines liberalen Egalitarismus (Frankfurt a. M.: Suhrkamp). 
Hall, R. B., and T. J. Biersteker. 2002. The Emergence of Private Authority in Global Governance (Cambridge: Cambridge University Press).

Hertz, N. 2001. The Silent Takeover: Global Capitalism and the Death of Democracy (London: William Heinemann).

Hoffman, W. M., and R. E. McNulty. 2009. "International Business, Human Rights, and Moral Complicity: A Call for a Declaration on the Universal Rights and Duties of Business," Business and Society Review 114(4): 541-70.

Hsieh, N. 2009. "Does Global Business Have a Responsibility to Promote Just Institutions?," Business Ethics Quarterly 19(2): 251-73.

Human Rights Watch. 1999. The Price of Oil: Corporate Responsibility and Human Rights Violations in Nigeria's Oil Producing Communities (New York: Human Rights Watch). Available online at http://www.hrw.org/reports/1999/nigeria/.

International Council on Human Rights Policy. 2002. Beyond Voluntarism: Human Rights and the Developing International Legal Obligations of Companies (Versoix: International Council on Human Rights Policy).

Kant, I. 1996. The Metaphysics of Morals, trans. Mary Gregor (Cambridge: Cambridge University Press).

Klein, N. 2000. No Logo: Taking Aim at the Brand Bullies (Toronto: Vintage Canada).

Kline, J. M. 2005. Ethics for International Business: Decision-Making in a Global Political Economy (London; New York: Routledge).

Kobrin, S. J. 2009. "Private Political Authority and Public Responsibility: Transnational Politics, Transnational Firms and Human Rights," Business Ethics Quarterly 19(3): 349-74.

Kutz, C. 2000. Complicity. Ethics and Law for a Collective Age (Cambridge: Cambridge University Press).

Levy, C. J. 2010a. "Microsoft Moves to Help Nonprofits Avoid Piracy-Linked Crackdowns," New York Times (October 17): 6.

2010b. "Using Microsoft, Russia Suppresses Dissent," New York Times (September 12): 1, 15.

Lukes, S. 1990. "Perspectives on Authority," in Authority, ed. J. Raz, 203-17 (New York: New York University Press).

Matten, D., and A. Crane. 2005. "Corporate Citizenship: Toward an Extended Theoretical Conceptualization," Academy of Management Review 30(1): 166-79.

Micklethwait, J., and A. Wooldridge. 2003. The Company. A Short History of a Revolutionary Idea (New York: The Modern Library).

Office of the High Commissioner for Human Rights. 2004. "OHCHR Briefing Paper: The Global Compact and Human Rights: Understanding Sphere of Influence and Complicity," in Embedding Human Rights in Business Practice, ed. UN Global Compact Office and OHCHR, 14-26 (New York: UN Global Compact Office). Available online at http://www.unglobalcompact.org/docs/issues_doc/human_ rights/Resources/embedding.pdf.

Pogge, T. 2002. World Poverty and Human Rights (Cambridge: Polity Press).

Prest, M. 1995. "Global Heroes, Local Zeroes,” The Observer (November 19): 4. 
Radon, J. 2005. “'Hear No Evil, Speak No Evil, See No Evil' Spells Complicity," Compact Quarterly 2005(2). Available online at http://www.enewsbuilder.net/ globalcompact/e_article000381758.cfm?x=b11,0,w.

Ramasastry, A. 2002. "Corporate Complicity: From Nuremberg to Rangoon. An Examination of Forced Labor Cases and Their Impact on the Liability of Multinational Corporations," Berkeley Journal of International Law 20(1): 91-159.

Ratner, S. R. 2001. "Corporations and Human Rights: A Theory of Legal Responsibility," The Yale Law Journal 111(3): 443-545.

Rawls, J. 1971. A Theory of Justice (Cambridge, Mass.: Harvard University Press).

Raz, J. 1990. “Introduction,” in Authority, ed. J. Raz, 1-19 (New York: New York University Press).

Reuters. 1995. "Shell Expresses 'Deep Regret' at Nigerian Hangings," Reuters News (November 10).

Rowell, A. 1995. "Environment—Trouble Flares in the Delta of Death," The Guardian (November 8): 6.

1996. Green Backlash: Global Subversion of the Environmental Movement (London: Routledge).

Santoro, M. A. 2009. China 2020: How Western Business Can-and Should-Influence Social and Political Change in the Coming Decade (Ithaca, N.Y.: Cornell University Press).

2010. "Post-Westphalia and Its Discontents: Business, Globalization, and Human Rights in Political and Moral Perspective," Business Ethics Quarterly 20(2): 285-97.

Scheffler, S. 2001. Boundaries and Allegiances. Problems of Justice and Responsibility in Liberal Thought (Oxford: Oxford University Press).

Scherer, A. G., and G. Palazzo. 2007. "Toward a Political Conception of Corporate Responsibility: Business and Society Seen from a Habermasian Perspective," Academy of Management Review 32(4): 1096-1120.

Scherer, A. G., G. Palazzo, and D. Baumann. 2006. "Global Rules and Private Actors: Toward a New Role of the Transnational Corporation in Global Governance," Business Ethics Quarterly 16(4): 505-32.

Scherer, A. G., G. Palazzo, and D. Matten. 2009. "Introduction to the Special Issue: Globalization as a Challenge for Business Responsibilities," Business Ethics Quarterly 19(3): 327-47.

Shue, H. 1996. Basic Rights: Subsistence, Affluence, and U.S. Foreign Policy (Princeton, N.J.: Princeton University Press).

Soyinka, W. 1996. "Nigeria's Long Steep, Bloody Slide," The New York Times (22 August).

Strange, S. 1996. The Retreat of the State: The Diffusion of Power in the World Economy (Cambridge: Cambridge University Press).

Sweeney, J., and C. Duodu. 1995. "Nigeria? Business as Usual with the General, Chaps," The Observer (November 5): 24.

Tripathi, S. 2005. "International Regulation of Multinational Corporations," Oxford Development Studies 33(1): 117-31. 
Ulrich, P. 2001. Integrative Wirtschaftsethik. Grundlagen einer lebensdienlichen Ökonomie (Bern: Haupt). . 2008. Integrative Economic Ethics: Foundations of a Civilized Market Economy (Cambridge: Cambridge University Press).

United Nations. 2008a. Clarifying the Concepts of "Sphere of Influence" and "Complicity." Report of the Special Representative of the Secretary-General on the Issue of Human Rights and Transnational Corporations and Other Business Enterprises, John Ruggie. Human Rights Council, Eighth session, A/HRC/8/16, available online at http://www.reports-and-materials.org/Ruggie-companion-report-15-May-2008.pdf.

. 2008b. Human Rights Council, Eighth session. Protect, Respect and Remedy: A Framework for Business and Human Rights. Report of the Special Representative of the Secretary-General on the Issue of Human Rights and Transnational Corporations and Other Business Enterprises, John Ruggie, A/HRC/8/5, available online at http://daccessdds.un.org/doc/UNDOC/GEN/G08/128/61/PDF/G0812861 .pdf?OpenElement.

2010. Human Rights Council, Fourteenth Session. Business and Human Rights: Further Steps Towards the Operationalization of the "Protect, Respect and Remedy" Framework. Report of the Special Representative of the SecretaryGeneral on the Issue of Human Rights and Transnational Corporations and Other Business Enterprises, John Ruggie, A/HRC/14/27, available online at http://www .reports-and-materials.org/Ruggie-report-2010.pdf.

Wettstein, F. 2009. Multinational Corporations and Global Justice: Human Rights Obligations of a Quasi-Governmental Institution (Stanford, Calif.: Stanford University Press).

. 2010. "For Better or For Worse: Corporate Responsibility Beyond 'Do No Harm,"” Business Ethics Quarterly 20(2): 275-83.

Wettstein, F., and and S. Waddock. 2005. "Voluntary or Mandatory: That Is (Not) the Question: Linking Corporate Citizenship to Human Rights Obligations for Business," Zeitschrift für Wirtschafts- und Unternehmensethik 6(3): 304-20.

Widerker, D. 1991. "Frankfurt on 'Ought Implies Can' and Alternative Possibilities," Analysis 51: 222-24.

Wiggen, O., and L. Bomann-Larsen. 2004. "Addressing Side-Effect Harm in the Business Context: Conceptual and Practical Challenges," in Responsibility in World Business: Managing Harmful Side-Effects of Corporate Activity, ed. O. Wiggen and L. Bomann-Larsen, 3-14 (New York: United Nations University Press).

Young, I. 2003. "From Guilt to Solidarity: Sweatshops and Political Responsibility," Dissent 50(2): 39-44.

2004. "Responsibility and Global Labor Justice," Journal of Political Philosophy 12(4): 365-88. 
Downloaded from https:/www.cambridge.org/core. University of Basel Library, on 11 Jul 2017 at 15:41:41, subject to the Cambridge Core terms of use, available at https:/www.cambridge.org/core/terms. https://doi.org/10.5840/beq20122214 